\title{
The Captivity Narrative and East-West Understanding in Aboulela's The Kindness of Enemies
}

https://doi.org/10.33806/ijaes2000.19.1.3

\author{
Charles Campbell \\ Sultan Qaboos University
}

\begin{abstract}
The American captivity narrative, like John Smith's account of his rescue by Pocahontas, derives its plot from accounts of captivity in the conflicts with Morocco and the Ottoman Empire. This cross-cultural provenance is reflected in Leila Aboulela's The Kindness of Enemies which can be usefully compared with the greatest of the American texts, The Captivity and Restoration of Mrs. Mary Rowlandson (1682), in regard to characters, plot, setting and sympathy for the colonized. In The Kindness of Enemies the captivity narrative goes both ways, into the East and into the West, and there are different ways and degrees of being a captive. Reading Aboulela's novel requires an analytic historical perspective on a Nineteenth Century Sufi rebellion during the Crimean War seen in counterpoint to the present besieged state of contemporary Britain. The novel broadens our common humanity as we share Natasha's problem of having "morphed into something completely different" on her difficult journey into the West, into history and into her divided consciousness. Aboulela presents, in place of projection, an involving interchange and interpenetration of people, events, imagery and (opposing) cultures. My reading, organized around the motifs of dreams and sword, follows the struggles of protagonist and narrator Natasha with intercultural guilt during her research into the Chechen resistance to Russian colonization.
\end{abstract}

Keywords: American literature, captivity narrative, imperialism, Orientalism

\section{Introduction: Migrant Muslim fiction}

Anglophone Arab literature has impacted the West at least since 1905 when the first Anglophone Arab poetry collection (Myrtle and Myrrh) appeared, followed by the first play (Wajdah) and the first novel (The Book of Khalid) in 1911, both by Ameen Rihani. All were published in the U.S.A., as was the first autobiography in 1914 (A Far Journey by Abraham Mitrie Rihbany).In 1923, Kahil Gibran's The Prophet was a best seller, typifying a tendency for these early Arab writers in English to present a "reductionist, monolithic idea of a 'spiritual' East" while also serving as cultural mediators at a time when Americans were seeking alternatives to the materialism of the West (Al Maleh 2009:2-3). Authors such as Ribhany sought acceptance in their new country and so wrote of their "migration and settling" in America by explaining why they left their native countries and striving to convince readers of their commitment to their new home. Such is the case with George Haddad's Mt. Lebanon to Vermont (1916), Ashad G. Hawie's The Rainbow Ends (1942) and Salloum Rizk's Syrian Yankee (1943). These memoirs, as well as novels like Edward Atiyah's The Thin Line (1951), were written "within the boundaries of Western discourse" (Al Maleh 2009:5-7).

In Great Britain, according to Sabine Schmidt, "Muslim literature in English first came to public 
attention with the Indian author Ahmed Ali and his novel Twilight in Dehli in 1940" (2016:33). Amin Malek supports her claim in his book Muslim Narratives and the Discourse of English (2005) when he writes, "Ali [launched the] literary tradition of Muslim writing in English" which began a movement that gives Muslim immigrants "a voice to project the other side of the story and to prove that spunky 'subalterns' can speak for themselves" (quoted by Schmidt 2003:33). The post-colonial generation of mostly British-Arab writers wrote of their social and psychological alienation at home and abroad in novels that often concerned the exile's return, like Tayeb Salih's Season of Migration to the North (1966, translated from Arabic 1969). Thus Edward Atiyah's novel Black Vanguard (1952) introduces the issues of hybridity and double-consciousness in a "quest for authentic self-representation" and anticipates an important theme of the post1970s generation described by Edward Said as "the great modern, or, if you like, post-modern fact, the standing outside of cultures" (quoted by Al Maleh 2009:11). That group of writers came into the West (mostly the U. K.), as a result of dispossession, war, flight from dictators, the search for a better life and the mobility of capital; and they write with strong links to Arab culture (Al Maleh 2009:12).

In The Anglo-Arab Encounter, Geoffrey Nash describes a new literary grouping he calls British migrant Muslim fiction, a movement which "began with Rushdie in the 1980s, cohered around an emergent British Muslim identity in the 1990s, and in the first decade of the twenty-first century saw the production of richly textured novels" which give non-Muslims insight into a little understood "religious identity that is becoming ever more deeply rooted in their midst" (quoted by Schmidt 2016:34). Many of these migrant Muslim authors are women, and their work tends to be "feminist, diasporic in awareness, and political in character" (Al Maleh 2009:13). Leila Aboulela fits into this group, which includes Fadia Faqir (Pillars of Salt 1996), Adhaf Soueif (The Map of Love 1999) and Ghada Karmi (In Search of Fatima 2002), although Aboulela cannot be considered to be very political until her most recent novel, The Kindness of Enemies (2015). Coming to Great Britain as students, these women found a space of personal and creative freedom; as a result, despite the prejudice they also encountered, they write about topics taboo in their native countries and so express non-conformist views and re-imagine cultural and personal identity (Al Maleh 2009:14-15). In their fiction, they "negotiate identities, mixed race, and issues of immigration and gender" and express the "wild strangeness" of "what it's like for those of us who live between identities"(Diana Abu Jaber quoted by Al Maleh 2009:33). Like Yasin, the protagonist of Jamil Mahjoub's Travelling with Djinns (2004), their stories cross multiple national borders in search of a new life narrative; and, as Said writes of Soueif, they do not "fall for the East versus West or Arab versus European formulas" but express the experience "of crossing over from one side to the other, and then back again indefinitely, without rancor or preachiness" (quoted by Al Maleh 2009:16). In his road novel, Mahjoub does this both physically and philosophically, as he drives with his son across Europe reflecting on European, Arab and American philosophy, religion and literature, 
mapping "the psychological, political, and historical geographies of post-colonial consciousness ... from a myriad of perspectives" (Michael Chaney quoted by Al Maleh 2009:19).

Thus in her memoir, The Language of Baklava (2005), Abu Jaber asks, "Why must there be only one home?" (quoted by Al Maleh 2009:35); while Mohsin Hamid, author of The Reluctant Fundamentalist (2007) believes the civilizations we cling to and fight over are mere illusions consisting of "arbitrarily drawn constructs with porous, brittle, overlapping borders" (Hamid Discontent and its Civilizations 2015:7), illusions that take us in by the hard fact of their violence. For Hamid to be human is to be hybrid; and one positive result of the mostly brutal regime of globalization is that we are free to invent ourselves and to realize "our common hybridity" (2015:9). What these migrant Muslim writers, like Mohsin, Hamid, Souief and Aboulela are doing is reimagining human community, seeking the way we can live now. The basis for such a literary art is seen by Edward Said early in the anti-colonial movement in Tagore, for example, when he argued that, since the nation state is an "unforgiving receptacle of power for producing conformity," the goal must be "not a competing nationalism" but "a creative solution to the divisiveness produced by racial consciousness" (quoted by Said 1994:215). Similarly, he quotes Fanon in The Wretched of the Earth (1961) that the revolutionary goal of "the Third World ... should be to try to resolve the problems to which Europe has not been able to find the answers" (1994:195). Said concludes that the resistance to imperialism "is an alternative way of conceiving human history" which is "based on breaking down the barriers between cultures" and finding "larger, more generous human realities of community among cultures, peoples, and societies" (216-217).

Such a vision is necessary now more than ever. Aboulela's recent books-Minaret (2005) and Lyrics Alley (2010) have appeared in a post 9/11, post 7/7 Britain where Islamophobia is on the rise and the government has put into place policies restricting the legal rights and enforcing surveillance of its Muslim population. The Prevent policy plays an important part In The Kindness of Enemies, particularly as it impacts education by restricting access to information and making spies and informants of teachers. It is a time of what Geoffrey Nash calls a Kultur kampf, a cultural struggle against Muslims, in his book Writing Muslim Identity (2012). Although most Muslims do not want to be in a war with the West, he writes, they "have become objects of suspicion and more insidiously, a war of words and images has been unleashed against them," launched by western writers and media (1). This notoriety has created a market for books by Muslims and placed them in university courses, although it is "a pity that this [new] visibility was filtered through "terror"' (Al Maleh 2009:2).

Nash points out that Arabs writing in the West increasingly see themselves as Muslim writers, "for whom religion [not rebellion] is a primary identity marker" (2012:4). This is especially true "given their minority status in secular liberal societies" and even more so after the 1989 Rushdie Affair and the terror attacks of 2001 and 2005 which have resulted in a re-emergence of the binary Us vs. Them mentality in the U.K., with the "Us" being a hegemonic secular self- 
expressed by writers like Sam Harris, Martin Amis and Samuel Huntington and the "Them" being people such writers see as a monolithic Islamic threat to western civilization (8-11). Nash sees two types of Muslim fiction emerging in this context. First, that of the native informant or "brown sahib" writers who affirm an Orientalist hegemonic secular view of Muslims "largely in terms of female-disabling, fanatical, and aggressive characteristics" (e.g. Rushdie, Kureishi and Monica Ali). On the other hand, he sees neo-Muslim writers, like Aboulela. who rewrite "traditional, ethnic views of Islam and Muslims in terms of a twentyfirst century global Islam" (26).

For Aboulela, paradoxically, it is "the secularized, godless western metropolis" that provides "the space in which an individualized faith commitment can grow"; Nash quotes her on this: "I have always wanted to write about what it feels like to have faith in the modern secular world" (45). Wail Hassan compares Aboulela's fiction to that of Taleb Saleh in being defined "against the values of the secularist, Orientalist, Islamophobic West," but whereas Saleh writes "narratives of failure ... hers are narratives of redemption and fulfillment through Islam" (quoted by Nash 2012:45). Aboulela's "fiction represents not so much a species of Islamic 'writing back' to Western society, as an exercise in acculturation to globalisation conducted from within the territory of the dominant discourse(s) since the language of encoding is English" (Nash Anglo-Arab Encounter quoted by Schmidt 2016:105). Aboulela presents a "transnational Islam" through her "multinational characters who celebrate the global ummah and its Islam, in which ... 'the connection between a religion, a specific society, and a territory' are blurred" (Oliver Roy quoted by Schmidt 2016:106). Further, this hybrid nature of her characters and stories "enter upon the dominant discourse and estrange the basis of its authority" (Homi K. Bhabha quoted by Schmidt 43). In this way her novels "lead to the assumption that successful identity formation, a supranational Islam as well as the culture of East and West are indeed compatible" (Schmidt 106).

In contrast to the native informant writers, as well as to such western writers about Islamas Amis, DeLillo and Updike (see Nash 2012:101-108), Aboulela finds that "the [western] metropolitan centre which is cold and closed off to the migrant is not so much a site of conflict, and even less one of vengeance or self-destruction, but incorporated instead into the providential scheme" (Nash 2012:46). Frederick Jameson has argued, in his essay "Modernism and Imperialism," that E.M. Forster uses the providential schemes of his novels to create a social utopia (1990:56); Aboulela, in novels like The Translator and Minaret, uses hers to create "spaces that are possible heterotopias," places of fulfilling difference, like the kitchen of Najwa's employer and the women's meeting hall in the Regent Park mosque in Minaret, places where the protagonist "defies her impossible homecoming, her 'displaced place', located within interruption, time-lag, receded memory" (Cariello 2009:349). For Aboulela and her protagonist, Islam and sharia are personal matters. In this she is affirmed by Mohsin Hamid who sees in Islam not a monolith but "multiplicity" (2015:224): "There are more than a billion variations of lived belief" among Muslims (220). 
She finds home not by returning to Sudan but by negotiating her migrant status in "what Homi K. Bhabha calls the interstices of modernity" (Cariello 2009:342).

Najma journeys to the umma which "transcends national contexts of origin and provides an alternative all-female community." Aboulela's protagonists' movement between different time periods and "geographic frames" shows "the complexity of post-colonial women's self-fashioning and the continuous negotiations that self-identification as Arab and Muslim and (partly) British requires" (Moore 2012:80-81). Said sees this as part of Arab diasporic writing in general: 'All of us speak of awdah, 'return,' but do we mean that literally, or do we mean 'we must restore ourselves to ourselves'?" (quoted by Al Maleh 2009:45).Therefore "Najma's journey . . . does not require a geographical return" (Moore 2012: 80).

According to Lindsey Moore, "Aboulela's protagonists . . . claim a (nonexclusive) British identity [but] they privilege a supra-national space of belonging and thereby challenge the frame . . . of the nation" (2012:76). She answers Tagore's call. According to Geoffrey Nash, "Aboulela's protagonists with draw from history and evince 'supra-political' attitudes" (cited by Moore78). However, her new novel, The Kindness of Enemies has an historian as protagonist and her story frames an account of a very political anti-imperialist struggle which is the topic of her research. The frame narrative concerns the life of a Russian/Sudanese British Muslim Natasha (Hussein) Wilson, including how the Prevent policy impacts her as an educator in Britain. In the spirit of Mohsin Hamid's novel The Reluctant Fundamentalist which talks back to Americans from the perspective of the victims of America's vengeful and inhumane reaction to 9/11, Aboulela incorporates the victim's side of what followed 7/7 in Government policy towards Muslims, especially in regard to surveillance and restriction of access to their own history. In a recent article on The Kindness of Enemies, Yousef Awad provides an illuminating analysis of Aboulela's interweaving of the history of a Sufi revolt against imperial Russia and the present-day stereotyping and victimization of British Muslims under CONTEST, the Government's post 7/7 counter-terrorism strategy. Awadh shows how the novel offers an alternate account of Muslim resistance and endurance in the face of injustice by focusing on "the Sufi Muslim . . . represented by Malak in the contemporary plot and Imam Shamil in the historical plot" (78).

In a marked departure from her earlier work, Aboulela's protagonist, Natasha, is a secular Muslim whose vision of her own identity is screened by her British identity. Rather than the feminist-inflected romance form of her previous novels, Aboulela's narrative follows the form of a captivity narrative, a narrative form associated with imperialist expansion, especially in America but also in the Muslim world. Her story is a captivity narrative of great complexity, involving inter-cultural journeys through time and space and acts of captivity by Muslims and the Western Powers in the past and in the present.

The Kindness of Enemies stands as an important addition to the British and American tradition of captivity narratives while also making a profound contribution to mutual understanding between the Muslim world and the West. 
Hers is among a small number of such narratives which transcend their oppositional basis to see both sides of the conflict that results in cross-cultural captivity--in her case, the ongoing conflict between the Islamic world and the Christian West. This study will, first, place her novel among this select group of captivity narratives that work to comprehend rather than to judge the culture of the captors in relation to that of the captives. Then I will show how Aboulela's novel considers different levels and sorts of captivity by interweaving an historical account of a nineteenth century liberation struggle in Chechnya with the story of the historian's own in-between state in the contemporary struggle between the Islamic world and the West. I will show how Aboulela creatively and humanely complicates the traditional captivity narrative, using dreams, symbolism, myth and realism to convey a vision that points the way to intercultural understanding and synthesis. In The Conquest of America, Tzvetan Todorov asks "What to make of the other?" (1992:4) and shows that the European encounter with the indigenous American tribes resulted in "a destruction on the order of 90 percent or more" of the native population (133). Asking the same question, Aboulela indicates that other, more imaginative, outcomes are possible.

There are clues in the novel that the reader should be aware of these parallels. When her student $\mathrm{Oz}$ describes Natasha's account of a Russian film about Shamil's resistance to Russian conquest during the Crimean War as being "like cowboys and Indians," she comments in her mind in her academic discourse:

But he was not so off point. The comparison had been made before by sympathetic historians. The Caucasus represented as Russia's wild west, Shamil the noble savage, as magnificent and inscrutable as a Native American chief (Aboulela 2017:13).

This reading of The Kindness of Enemies examines the implications of that historical and inter-textual element in the novel. I study Kindness in the frame of reference of the captivity narrative in American literature, to show how this frame of reference contributes to its rich meaning and elegant form.

\section{Migrations in captivity}

Some documents of imperialism display interesting cross-cultural characteristics. Such is the case with captivity narratives of Britain's conflicts with Morocco and the Ottoman Empire in the Mediterranean which were retold in adapted form during the conquest of America. This is so because the tales were known by the colonists from "those of their countrymen who were captured by the powers of Barbary and Islam" (Colley 2002:140). In fact, the first American captivity narrative, the mythic story of John Smith and Pocahontas (1624), was "the work of a man previously captured while fighting against Ottoman armies" (141). Smith also wrote an account of his captivity in Turkey in which his escape, there too, happened with the intercession of a (Muslim) princess.

Captivity narratives are ways of constructing the other, often as a projection and "as a strategy of colonial domination," but Pauline Turner Strong suggests we should see them rather as "intercultural encounters" or "convergences" in order to comprehend "the relationship between representation and domination" and "how 
identification with an Other underlies and complements even the most extreme opposition to that Other" (1999:6-9). In The Kindness of Enemies Leila Aboulela weaves the threads of three captivity narratives into a novel of subtle, complex and inspiring multicultural interactions, a narrative design woven across a 200year historical divide that allows a non-projective, integrative encounter with Muslim and Western others.

"David, leave them alone," says Anna to her husband, a general in the Russian army, in The Kindness of Enemies. This is after her return to him from a ten-month captivity at the hands of Shamil, leader of a $19^{\text {th }}$ century Caucasian rebellion against the tsar. Aboulela presents her story of the East from the Western side, albeit in the voice of Natasha, an overweight Sudanese-Russian would-be assimilated immigrant to the U.K. Natasha (Hussein) Wilson is an academic in Scotland doing research on those Caucasian wars who has changed her last name from Hussein to Wilson and who very much wants to fit into British society, which to her is the university, publications and promotion. In pursuit of her fitting-in, she cooperates with her department head in making a report to the government on a student who is her research subject and friend and has been arrested by the police as a result of his research for her course. The student is $\mathrm{Oz}$, who shares Natasha's fate of an unfortunate name in post-9/11 and 7/7 Britain, since it is short for Osama. She does not protest when her computers and phones are seized in the investigation, nor does she take any action during Oz's ten-day detention. So she is no jihadi, but an historian of jihad and, in particular, of Oz's ancestor, Imam Shamil, the Caucasian (Chechan) freedom fighter during the Crimean War.

The narrative alternates between Natasha's first-person account of events in her life (Oz's capture, her problems at school, her surveilling and reporting on Muslim students, her estranged father's death in Sudan) and the stories of the kidnapping of Shamil's son by the Russians and the responsive kidnapping, fifteen years later, of Princess Anna of Georgia to serve as a counter for Shamil to use in getting his son back. Based on historical fact, Anna's story nonetheless fits into the genre of English and American captivity narratives. The earliest of these concerned Arab or Islamic captors, given the Crusades and the wars between European powers and the Ottoman Empire. The best of the Oriental novels that came out of that period of interface is Samuel Johnson' Rasselas which, like The Kindness of Enemies, presents in its central section a sympathetic account of the Arab Muslim kidnapper, who in Johnson's novel is also in rebellion against an imperial power, the Ottomans.

In American literature captivity narratives are an important early literary form that expresses the inter-cultural conflicts and interactions between the European settlers and the indigenous people. This tradition is interesting here because of some parallels in plot and, especially, because the expansion of American power into other's lands has caused the present extremely violent confrontation between Muslims and the West, a fact which makes the literary parallels noteworthy. Due to the constant conflict that westward expansion involved, between 1675 and 1763 an estimated 1,641 New Englanders were taken 
hostage (Vaughan and Richter 1980:53) while in the nineteenth century hundreds of women and children were captured during the Plains Indian wars (White1969:32). In those same years, hundreds of first-hand captivity narratives were published, as well as fictional treatments including James Fenimore Cooper's The Last of the Mohicans (1826) and The Deerslayer (1841). The tradition continues in America in such books as, Patty Hearst's Own Story (1988) and Jeffrey Toobin's account of her 1974 kidnapping by the Symbionese Liberation Army (SLA), American Heiress (2016). The greatest of the early firsthand accounts is the Narrative of the Captivity and Restoration of Mrs. Mary Rowlandson (1682). Rowlandson's narrative is motivated by Puritan ideology which makes her ordeal an account of redemption. However, she also shows how the colonists constructed the other. Mainly they constructed the native people as the Enemy, as agents of Satan opposing their divine mission in the wilderness. And yet, Rowlandson, a keen observer and accurate reporter, somehow, in the process of construction, shows these hellish enemies as equally human to herself. Like Anna in Aboulela's novel, Mary sees her home destroyed and friends killed when she is captured; she loses a daughter on the first Remove, as she calls the Indians' successive retreats into the forest, as Anna loses her daughter on the march into the Caucasus Mountains. Reduced by hunger, Mary steals from a captive child; Anna takes food meant for her own son. Rowlandson presents a humane and distinguished portrait of Metacomet, the Indian leader in King Philip's War, also known as the First Indian War (1675-78). In the same spirit, Aboulela, through the medium of her troubled historian Natasha's account of Anna's captivity, presents a sympathetic account of Imam Shamil, a Muslim rebel leader, and does so within our present-day context of ever more violent and vicious conflicts between Muslims and the West.

The best captivity narratives are like this. At times of violent cultural wars, which in our times are wars of Western domination, they make a sympathetic journey into the country of the enemy and discover humanity there. While her narrative confirms the truth of Puritan ideology in order to show the workings of Providence and her own redemption, Rowlandson also shows how some Indian families take her in out of the cold and feed her and some turn her away; she admires how they live on ground-nuts while in flight and survive the harrowing conditions of winter life on the run. She marvels at the "strange Providence" that allows the Indians to outwit and elude the pursuing English army. The Bible which enables her to make typological parallels between scriptural events and her ordeal as it unfolds is the gift of an Indian who took it on a raid and gives it to the only Christian lady he knows. Johnson's Arab in Rasselas (who, like Anna's kidnapper, admits to being a bandit) gives a well-reasoned political argument on why he lives in rebellion against the Turkish conquerors of Egypt (see Campbell 1990:268-271, and Campbell 1994). The Kindness of Enemies, too, constructs the other in a sympathetic way; however Aboulela's fictional world, like our real world, presents a very complicated interchange and interaction of the West and its Other; and, while Rowlandson returns to her colonial Christian community, Aboulela's narrative glides between East and West. In her novel this complexity 
involves her protagonist's life and the lives of her historical characters reverberating within the finely layered and interactive structure of the novel.

In The Kindness of Enemies the captivity journey goes both ways, into the East and into the West, and there are different ways and degrees of being a captive. This is especially true in the in-between condition of diasporic Muslim writers, like Natasha, who work in the intolerant Kultur kampf atmosphere of post 7/7 Britain. This novel is a delicately tuned, deeply felt and finely expressed account of the people and forces moving, aggressing, attacking, retreating, defending, responding and reacting to the cultural clashes between the Muslim world and the West. Even Natasha, the narrator/protagonist/historian is a captive of sorts. She is a willing captive as the kidnapped women who married Indians are called in the American tradition, as in John Ford's film The Searchers (1956), the great modern captivity narrative, or in the case of Patty Hearst who, in her nineteen months with the SLA, goes from "captive [to] bank robber, gunfighter, radical revolutionary, feminist and fugitive" (Graebner 2008:6).Politically and culturally Natasha moves in the opposite direction from Hearst. In the term from her own historical account for tribes who abandon Shamil and go over to the Russians, Natasha "regresses"; she gives in to the power and attraction of the West. She feels guilty over her name change, her abortion and her treachery toward friends in favour of her career. This is her captivity by the West, becoming willingly subject to its blaming for appearances, its hypocrisy and its demand for "success." She will succeed despite being black, Muslim and obese. Her research is her yearning back towards her other culture where her original values lie. Her story takes her back to Sudan and to her ailing father, but he is already dead when she arrives. Now fully an orphan, she is held there awhile by her memories and the tragic circumstances of her childhood sweetheart, now a widower and sympathetically fat like her. Romance beckons, but Natasha, in the end, remains alone.

Natasha sees herself as a bifurcated monster in her dreams:

I dozed and I was standing on one of the peaks of the Caucasus, balancing on the edge of a ledge. From the top of my head all the way down in one straight swoop, I split in two, half-human and half-reptile. . . . In the logic of dreams I was not embarrassed that I was naked, nor that a part of me was inhuman. With my left hand I ran my fingers over a pattern of scales on my right shoulder, ridges of shell, leathery grooves. . . . What perplexed me the most was that I had split vertically rather than horizontally. It was natural to be like a centaur or a sphinx; it was usual to have a full human head. But I had failed; I had morphed into something completely different (Leila Aboulela The Kindness of Enemies 2017:80$81)$.

Linked to the captivity story and suggestive of the problematic identity of cross-cultural migrants as well as the structure of the novel, this passage describes on its primary level Natasha's sense of self. Her in-between cultural state creates a personality in conflict with itself: 
But I was a Sudanese woman. . . No matter how much I changed when I came to Britain, changed my behaviour and my thoughts, there would be layers of me, pockets, membranes and films that would carry these other values and that other guilt (146).

Her story is about the impossibility of complete assimilation and the need to accept alterity, to embrace the other, culturally and in oneself.

The other main characters in her personal story are also in-between in various ways: Malak, a well-regarded British actress who finds peace in her Sufism, and her son, the great-great-great grandson of Shamil, who is arrested under suspicion of terrorist conspiracy and thus becomes another captive. His arrest occurs in counterpoint to the kidnapping of Jamaleldin, Shamil's son, in the alternating historical chapters. In the story of Shamil, the captive is his first-born son, whom we first see as an eight-year old fighter at the Russian siege of Akhulgo in 1839, gathering rocks to hurl down on the Russian attackers. We also see him rip open the belly of a Russian soldier, stabbing from below. Fifteen years later, an allied tribe of Chechan fighters, on a raid into Georgia, kidnap Anna to serve as an exchange for Jamaleldin.

This double switch is the pivot of the novel. Then, there is the double switch back, when the captives on either side are released and return to their homes and families, each with some regrets about leaving and new insights into the enemy culture. In the process the reader learns a little-known history of a liberation struggle in Eurasia in the nineteenth century and also about two historical Sufi figures and how Sufism served as the inspiration for a war of liberation. Imam Shamil and his teacher Jamal el-Din come to us believably and intimately, in their piety, sincerity, austerity and humanity. Shamil, whom we see through Anna's perspective, as soldier, religious devotee and father comes across as very nearly heroic, with a mythic sense to his childhood, Sufi education and campaigns against the Russians which last for thirty years.

The multiple layers of Aboulela's novel take the reader, through Anna's life and research and then through the captivity story of Anna into the Muslim world and, as in Rasselas and in Paul Bowle's The Sheltering Sky (1949) and other oriental captivity tales, the journey takes us into a harem, that site of Western fascination, attraction and abomination. Orientalist paintings, as well as pornographic novels like The Lustful Turk (see Said 1985:8), show "a recurring theme of the idle, sensuous harem woman, powerless except for her sexuality" (Latifa 2018). What we find in the harem in The Kindness of Enemies (as in Rasselas) are scenes of women's power politics, friendship, conflict and solidarity expressed, in Kindness, between Anna and the three wives. Zeidat, the first wife, browbeats Anna demanding a great ransom, as well as the return of Jamaleldin. (Her father, Sheikh Jamal el-Din himself, considers her a "fanatic.") The other wives, Ameena and Chuanat, befriending Anna, present Arab womanhood as strong and complex within the traditional structure of the harem. The corresponding site of conflict today seems to be the hijab under which, in a failure of imagination, we cannot imagine a person. 
All of the drama and interest of these characters comes through Natasha, the historian, as do the dreams both in the present-day and historical layers of the narrative, which add another layer of depth. Natasha's cultural conflict is internal, complicated, unresolved (except as the historical narrative is her dream of resolution). Natasha wants to fit in and has gone against her Sudanese background in having an abortion. She "shops" her students, including Oz, in order to ensure her own job security and advancement. She feels herself to be a "hypocrite" in her drive "to grab yet another opportunity," yet she deserts Oz and Malak and, worse, testifies against $\mathrm{Oz}$ on the basis of what she'd seen as their honoured houseguest while doing her research on Shamil. She is very conflicted in her effort to assimilate. Part of the courage of this book is to make Natasha a rather shabby person. However, in her historical narrative, she presents a vision of reconciliation which escapes her in her personal life.

One takes an interest in Natasha in her relationship to Oz and Malak, who are better people and who have carried on the legacy of their family by knowing its history and, in Malak's case, practicing the Sufism that was the inspiration for Imam Shamil. Thus the reader learns something of Sufi mysticism and will never forget Jamal el-Din's key point of philosophy: "The world is a carcass and the one who goes after it is a dog," which echoes through the story in different characters' minds and certainly reflects on the "regression" of Natasha.

Another courageous aspect of Aboulela's book is its imagery. The sword of Shamil, still in the possession of his descendants, is the opening image of the novel: "Allah was inscribed on the blade in gold" (3).There is no pulling of punches about jihad being solely a pacifist endeavour. It is using the phrase "Sword Of Shamil" as his e-mail address, downloading a terrorist handbook as research for Natasha's course, plus the scene of him cutting the heads off snowmen with the sword, which Natasha details in her report, that get $\mathrm{Oz}$ into trouble; and the sword is confiscated by the police. Next we see the sword in the past when Shamil consults with his spiritual counselor, hanging on a nail in the wall, as (in the words of Jamal el-Din) "the great Shamil is cleaning my shoes!" (63). Later, Anna sees the sword hanging in Shamil's bedroom when she goes there with Ameena. The sword becomes a complex symbol of conflict, family, romance, justified rebellion, spirituality and misunderstanding. Like Changez in Hamid's The Reluctant Fundamentalist, Abouleila answers back to American power; she does not avoid or obscure the need to resist western aggression. Her novel countenances both Malak's Sufi definition of jihad as "an internal and spiritual struggle" and her son's point that "if Shamil were here today he wouldn't have sat back and let Muslim countries be invaded" (9-10).

Dream imagery adds depth to the novel's layers of history, culture and consciousness. Guilty over her abortion, Natasha dreams of a dead baby (which just might be alive) in a drawer (113) after the scene of Anna dropping her baby on the flight into the mountains (100), whom we learn later was immediately crushed by horses" hoofs, and just before we read of "Anna, on hands and knees, sifting through rocks and brambles looking for the impossible," her lost infant (115-116).Other links between the layers also work through dreams, which are 
significant for Shamil and his teacher as Sufis and hold intriguing significance in this novel for understanding both the life of Natasha and her history of Shamil. For Anna, her captivity has a romantic component realized in a dream. When Zeidat threatens her with being given away to a tribal chief, Ameena, the youngest wife, says "She's jealous of you. That's why. She knows what's on Shamil Imam's mind. If the ransom isn't paid, he will keep you for himself" (199-200). That night Anna has the dream Shamil promised to send her when he left on a campaign. It is a mystical dream of perfect, transcendent and joyous integration with her native countryside. This too is part of the intricate network of interactions and exchange between East and West in the novel.

When Madame Drancy, Anna's children's governess, who is fascinated by harem life, says living with people so different from oneself is "a marvel," Anna thinks, "A marvel. For a person to send another a dream would indeed be a marvel" (198). That night she has the dream. There is this frisson of the marvelous in the Sufi atmosphere of the history chapters (also with Malak in the contemporary ones), and there is a sense of hope in the exchange of captivity in Anna's dream: "Without hunger. Only harmony. Only light. . . . Everything is close, larger, infinitely interesting. . . . There is no gap between herself and her surroundings" (200). Later, restored to her husband and pregnant, Anna dreams that Shamil comes to touch her belly and to name and bless the child. We suspect she might have become a willing captive in time.

On the other hand, Natasha's dream in which she becomes "half human, half reptile" shows a negative personal outcome of her captivity by the West. This is her guilty regressive attitude towards her own willing captivity, her selfdestructive alienation. Yet it also represents, in one symbol, the great, complex double vision of cultural exchanges, interactions and comprehensions in the novel as a whole which seems bent in multiple ways to imagine out of the raw material of divisions and conflicts some new peaceful human wholeness.

Reading this novel western readers must journey into enemy territory. We learn the history of a Sufi jihad which functions in opposition and even, to some extent, explanation, of present day jihadis. Through $\mathrm{Oz}$ we see how a British student of his generation would be attracted to an austere tradition of wisdom, spirituality and resistance to imperialism and thus be mistaken for a jihadi by the authorities. We see how his detention and the bias, labeling and betrayal involved can turn him toward becoming more like the stereotype. He drops out of school at the end, becomes less grounded, more aimless, fulfilling some of the "red flags" on the form Natasha fills out to expose her students to police scrutiny. Oz's experience is not unusual for students under Schedule Seven counter-terrorism powers which have led to McCarthy-like repression and police abuses with the effect that "Muslims face a 'worsening environment of hate' in the U.K." (Hooper 2015 quoting an Islamic Human Rights Commission report).

As an informant under the Prevent programme in schools, Natasha is a guilty actor and also self-destructive, because she shops $\mathrm{Oz}$, at whose house, with his mother, she has her only contented moments in the book. She does this because of her department head's question "how would it look for you" if he turns 
out to be guilty and she did not report him? Her treachery is a self-betrayal, for it is with Malak and Oz that she feels "like I was worth something," and her conflicted life for once makes sense: "We were ringed by wider spaces, the past, the future, the Caucasus, the Grampions [there in Scotland], my memories of Khartoum" (184).

Natasha struggles with her intercultural guilt; however the West avoids any contemplation of its guilt in the present violent East/West exchange. The novel reminds us that the struggle against external control of one's land and culture is as just now as it was then and thus of the West's unconscious guilt. The blank in the West's perception of the Middle East should contain the million dead people in Iraq, aside from soldiers, caused by the 2003 invasion, the 500,000 children who died for lack of proper medical supplies due to the earlier embargo and the rubble that once was home and society in Iraq, and also now in Libya, Afghanistan, Sudan, Syria and Yemen after Western or Western-sponsored intervention. Aboulela fills in this blank in Western consciousness with Shamil's description of his mountain village: "Akhulgo was reduced to what the Russians wanted it to be; the stench of the corpses, the wailing of children, houses and stables turned to rubble" (33); and in a speech of Zeidat to the captive Anna: "We need [the ransom] to build our villages again, the ones you burnt down, the trees you cut down, the crops you destroyed, the pastures you razed, the cattle you . . . shot down for no reason" (152). This puts it mildly. In our time, since 1991, the ArabMuslim world has been regularly under attack, by air (with bombers, rockets and drones), by blockade and by two full-scale invasions by the U.S. and its allies; and the onslaught continues today. The only viable and sustained resistance to this assault has been the Islamist. No matter their methods, that is true. And the West needs to closely examine its own methods and policies.

The novel's captives are all changed by their experience, joining Natasha in various kinds of in-between states. For Anna, it is her admiration for Shamil and his cause (he gives her a dream). Anna changes in relation to her husband and the enemy: When David's words are angry and vengeful, she "closed her eyes. They were unpalatable to her now-anger and revenge. They were too simple" (269). Anna's self-affirmation is the result of her captivity. There, she was fully respected by Shamil as the Queen of Georgia. She teaches her son born after her return to say his name as Ilia, Prince of Georgia, in the manner Shamil had used to address her. She wants Chuanat and her other friends in the harem to know that her first son, "Alexander, still chanted "la ilaha illa Allah" (282). She often dreams of Shamil's "presence. And in his presence was a force, a fullness that was sufficient, an end in itself" (282). Her world is now neither East nor West.

The other returned captive, still tied to Europe, Jamaleldin yearns for the lost sensuality and fine culture he grew to love in Petersburg and Warsaw (with its direct line to Paris), for art, beauty and pleasure. Jamaleldin dies young but without going back to war and with an atlas, books and paintings smuggled in from Russia by him in his last days. Jamaleldin makes the return journey to his native place, but he always feels apart from it, as Natasha does in Britain. He reconnects with Islam partly through a "regime of reintegration" carried out by his 
father and partly by finding elements in it that call to him personally, like the sensual beauty of the words when his father recites the Qur'an. Yet the boy who gathered stones for the battle and stabbed Russian soldiers in the belly is changed, in some ways similar to Anna: "Their logic was not his logic. He was saying peace and they were saying the resistance will win. He was saying Russia and they were saying jihad" (272). He re-learns enough of "his lost language" of Avar "to be able to urge [his father] towards one thing, peace" (274). He finds in his family "uninhibited love falling on him, voluminous and weighty" (271); but he also finds himself under surveillance. Those around him "shamelessly eavesdropped on every word he said" (274) and "his letters [were] scrutinised before they were sent" (275). He is still a captive. Zeinab, the "fanatic," enacts the equivalent of Prevention when she discovers a Christian ikon he has brought back from Russia which acts as damning evidence much as did Shamil's sword for Oz. In a further parallel with Oz's captivity in Britain, "all his belongings were confiscated. His books, his atlas, his globe" (273). When he begins to build his own house, people complain that "the design ... was in the shape of a cross"; and he allows them to "tear the whole thing down in a frenzy of self-righteousness and superstition. Public humiliation trampled his spirit" (275). Yet he conforms outwardly, dodging suspicion in order to "fit in" (273), like Natasha. His western education provides him a comment on his cultural repression which reflects on his in-between state as well as Natasha's guilt over Oz's detention: "Keep the company of wolves and you must learn how to howl. This was what the Russian proverb said" (273). Here Aboulela writes back to both sides in the war for cultural purity, another reverberation in this novel's echoic, interwoven narrative.

\section{Coming home to captivity}

Natasha is left more alienated from Great Britain but with some tiny bit of connection to Sudan and to Islam. In Sudan, she achieves "in a small way, faintly, marginally, tentatively," a feeling of belonging (303); she can chat long distance with her friends there, skipping "from Russian to English to Arabic," "without the need to prove, explain or distinguish myself. Nor squeeze to fit in, nor watch out of the corner of my eye the threats that my very existence could provoke" in Britain (324), where she remains. As she tells Malak, her "homesickness wasn't cured" (328). And when her academic department rejoices at Oz's dropping out of school, she feels an instrumental guilt: "I hid myself in the Ladies' and cried with anger, ashamed that, even now, I could not stand up for him" (323). She is as self-divided as ever. Yet, in her very last words of the novel, she begins to realize, through her continuing friendship with Oz's mother, "that what I was after was spiritual" (329). Like the reader, Natasha has learned much about the history and philosophy of Sufism in her research and, from Malak, about how it touches one's life. This is where the historical and personal narratives may intersect for her.

What the book shows, and does so authored by an observant Muslim woman, is there is no going back to nations pure and simple. There is no way to live a life of cultural purity, no matter how many reactionary governments are 
elected and despite the theories of Samuel Huntington (see his Clash of Civilizations, but see also Tariq Ali's riposte in The Clash of Fundamentalisms).Instead of seeing "intercivilizational conflict" (i.e. "tribal conflict on a global scale") as historically definitive and "particularly prevalent between Muslims and non-Muslims" (Huntington 1997:207-208), Aboulela imagines our continuing lives together in terms of gaining some knowledge of the other and of our own otherness and thereby imagining other possible outcomes. The Kindness of Enemies looks at the present and not so far into the past and expresses a more subtle vision of the interaction of East and West than mere conflict.

Such novels are required in these empathetically needy times. We need a different perspective on our mutual East-West history and a more imaginative vision of what we can do if we all remain each other's captives, as we will. We are all mongrels now, except in some deluded vision of cultural and racial purity. The clash of civilizations thesis is reactionary, dangerous and impossible of realization (i.e. an illusion), since it would require us to travel back in time. A vision of intercultural synthesis is called for.

No matter how difficult it is, we will have to do what Natasha is doing in the novel, trying to account for the transformations history has made in her selfhood. We must, like the captives in this and some previous captivity narratives, enter a multicultural life and consciousness. There is no turning back from that fate, whether you see it as a triumph or a defeat. Aboulela's novel offers, in opposition to the West's failure of imagination, a finely wrought conception of the other as believable, sympathetic, knowable people with depth and complexity and a history of justified resistance to imperialism. She urges us to make the difficult, imaginative, intellectual and political efforts required to escape our captivity by the past when Indians were seen as the bad guys and the West's violent expansion was seen as God's will. Aboulela's novel deserves to be read for the education it provides the reader in Muslim history and spirituality, but, above all, for its insistence on empathy and humanity in our collective construction of the other. It is a difficult work that insists on the difficult work of reconciliation. 


\section{Acknowledgment}

I would like to thank the anonymous reviewers of IJAES for their useful feedback on an earlier version of this article.

Charles Campbell (PhD)

Sultan Qaboos University

Muscat, Oman 


\section{References}

Aboulela, Leila. (2005). Minaret. London: Bloomsbury.

Aboulela, Leila. (2017). The Kindness of Enemies. New York: Grove Press.

Ali, Tariq. (2009). The Clash of Fundamentalisms: Crusades, Jihads and Modernity. London: Verso.

Al Maleh, Layla. (2009). 'Anglophone Arab Literature: An Overview'. In Layla Al Maleh (ed.), Arab Voices in Diaspora: Critical Perspectives on Anglophone Arab Literature, 1-63. Amsterdam: Rodopi.

Awad, Yousef. (2018). 'Fiction in CONTEST with history? Faith, resilience and the war on terror in Aboulela's The Kindness of Enemies'. International Journal of Arabic-English Studies, 18: 71-90.

Campbell, Charles. (1990). 'Image and symbol in Rasselas: Narrative fForm and "The Flux of Life"”. English Studies in Canada, 16 (3): 263-277.

Campbell, Charles. (1994). 'Johnson's Arab: Anti-Orientalism in Rasselas'. Abhath Al-Yarmouk, 12 (1): 51-66.

Cariello, Marta. (2009). 'Searching for room to move: Producing and negotiating space in Leila Aboulela's Minaret'. In Layla Al Maleh (ed.), Arab Voices in Diaspora: Critical Perspectives on Anglophone Arab Literature, 339350. Amsterdam, Ridopi.

Colley, Linda. (2002).Captives: Britain, Empire and the World 1600-1850. London: Jonathan Cape.

Graebner, William. (2008). Patty's Got a Gun: Patricia Hearst in 1970s America. Chicago: University of Chicago Press.

Hamid, Mohsin. (2007). The Reluctant Fundamentalist. Toronto: Anchor Canada.

Hamid, Mohsin. (2015). Discontent and Its Civilizations: Dispatches from Lahore, New York, and London. New York: Riverhead Books.

Hooper, Simon. (18 Nov. 2015). 'Muslims face "worsening environment of hate" in UK'. Al Jazeera.

https://www.aljazeera.com/indepth/features/2015/11/muslims-faceworsenin. (Retrieved on 9 March, 2018).

Huntington, Samuel P. (1997). The Clash of Civilizations and the Remaking of World Order. New York: Simon \& Shuster.

Jameson, Fredric. (1990). 'Modernism and Imperialism'. In Terry Eagleton, Fredric Jameson, and Edward Said (eds.), Nationalism, Colonialism and Literature, 43-66. Minneapolis: University of Minnesota Press.

Latifa (Linda Wilkinson). (2018). 'The Harem: Contrasting Orientalist and Feminist Views'. The Best of Habibi.http://thebestofhabibi.com/vol-19-no1-feb-2002/the-harem/ (Retrieved on 10 March 2018).

Mahjoub, Jamal. (2004). Travelling with Djinns. London: Vintage.

Moore, Lindsey. (2012). 'Voyages out and in: Two (British) Muslim women's bildungromane'. In Rehanna Ahmed, Peter Morey, and Amin Yaqin (eds.), 
Culture, Diaspora, and Modernity in Muslim Writing. 68-84. New York: Routledge.

Nash, Geoffrey. (2007). The Anglo-Arab Encounter: Fiction and Autobiography by Arab Writers in English. Oxford: Peter Lang.

Nash, Geoffrey. (2012). Writing Muslim Identity. London: Continuum.

Said, Edward W. (1985). Orientalism. Harmondsworth, Middlesex, England: Penguin Books.

Said, Edward W. (1994). Culture and Imperialism. New York: Vintage Books.

Schmidt, Sabine. (2016). Beyond the Veil: Culture, Religion, Language and Identity in Black British Muslimah Literature. Trier: Wissenschaftlicher Verlag.

Strong, Pauline Turner. (1999).Captive Selves, Captivating Others: The Politics and Poetics of Colonial American Captivity Narratives. Boulder, Colo.: Westview Press.

Todorov, Tzvetan. (1992). The Conquest of America: The Question of the Other. Transl. Richard Howard. New York: Harper Perennial.

Vaughan, Alden T. and Daniel K. Richter. (1980). 'Crossing the Cultural Divide: Indians and New Englanders, 1665-1763'. Proceedings of the American Antiquarian Society, 90: 23-99.

White, Lonnie J. (1969). 'White women captives of Southern Plains Indians, 1866-1875'. Journal of the West, 8: 327-54. 